CHAPTER 2:

\title{
Bulgarian Civic and Citizenship Education in Transition
}

\author{
Svetla Petrova
}

\begin{abstract}
In 2016, a new Pre-School and School Education Act was adopted in Bulgaria. This led to considerable change in the school system and in the concept of secondary education. The goal is a complete reform of the school system, school life, teaching content (in all school subjects), and teachers' training. This involves a new educational paradigm and has a profound impact on all aspects of education-promoting the intellectual, emotional, social, moral, and physical development of every child. Civic competence has recently become a focus of education policy. The current concept of civic and citizenship education reflects experts' agreement that the social mission of civic education is to harmonize the relationship between the individual and the state and to promote the successful integration of young people into society. Although significant changes in education have been made in recent years there are problematic areas related to the quality and efficiency of civic education in Bulgaria, which are still debated.
\end{abstract}

\section{Educational Context for Civic and Citizenship Education}

\section{Educational System in Bulgaria}

The Bulgarian educational system has its foundation in the Constitution (1991), which declares that education is a fundamental right for all citizens regardless of gender, social background, ethnic origin, or religion. This fundamental democratic principle of free access to education is confirmed in all normative documents regulating the functioning of the educational system. Schooling is compulsory up to the age of 16. (In 2016, mandatory pre-school education for children at five years of age was introduced). School education can be acquired at state, municipal, or private schools. With the exception of private schools, all education is free of charge. All grade 1 to grade 7 students, in all schools, receive free textbooks.

Schools in the country are primary schools (grade 1-4, ISCED ${ }^{1} 1$ ); basic schools (grade 1-7, ISCED 1/2); high schools (grade 8-12, ISCED 3); united schools (grade 1 - 10, ISCED 1/2/3), and secondary schools (grade 1-12, ISCED 1/2/3). Primary education includes two stages: elementary (grade 1 to 4) and gymnasium (grade 5 to 7 ) schooling. During ISCED 1 and 2 students are not divided into tracks, with the exception of relatively small numbers of students in some high schools, usually those with interest in mathematics and science. The first stage, grade $8-10$, is compulsory. The second stage, grade $11-12$, is elective and provides access to the universities. Depending on the instruction, school education is general, of special profile, and vocational. Students' admission to ISCED 1 and ISCED 2 depends on parental preferences (with the exceptions described above). Enrolment at ISCED 3 takes place according to the students' results in the external national assessment at the end of grade 7 . The high schools can be profiled (in fields such as mathematics, science, foreign language) or vocational. There are also schools specialized in sports, arts, culture, and for the needs of religious denominations.

1 ISCED = International Standard Classification of Education.

Svetla Petrova

email: sv_m_petrova@abv.bg

(C) IEA International Association for the Evaluation of Educational Achievement 2021

B. Malak-Minkiewicz and J. Torney-Purta (eds.), Influences of the IEA Civic and Citizenship Education Studies, https://doi.org/10.1007/978-3-030-71102-3_2 
Education administration is organized at four levels: national, regional, municipal, and school. The Ministry of Education and Science (MES) is the central public authority responsible for the kindergarten, school, and university levels. The Regional Departments of Education (RDE) are territorial units of the MES for the management and control of the education system at regional level. There are 28 units, corresponding to the territorial and administrative structure of the country. The school is a legal entity. The autonomy of the schools-both managerial and financial-was considerably extended during recent years. Each school's autonomy includes school management and particular aspects of instructional organization. Instruction in the schools is implemented according to the state educational standards and curriculum framework in every school subject (Ordinance № 5/30 November 2015).

New for the education system is the introduction of innovative schools-schools which achieve a higher quality of education through introducing new teaching methods or innovative elements in the development of teaching content, curricula, and syllabi. Recently Personality Development Support Centers have also been created to support the inclusion, instruction, and upbringing of children, as well as to cultivate their interests and capabilities. These are for students with special educational needs and for those with outstanding talents.

\section{Brief History of Civic and Citizenship Education in Bulgaria}

The modern Bulgarian state (the Third Bulgarian Kingdom) was re-established after liberation from the Ottoman Empire in 1878. Bulgaria became a constitutional monarchy with a democratic governmental system, free market economy, and a multiparty political system. The Tarnovo Constitution was adopted in 1879. With several amendments, the Constitution remained the fundamental law of Bulgaria until the end of 1947. Bourgeois-liberal in character, the constitution was considered advanced for its time. It granted a wide range of individual liberties; it required all Bulgarians to obey the law, pay taxes, send their sons to the army for a two-year period, and educate their male and female children at the primary level. According to the Constitution, education is "the basis for the progress of the people" and primary education is mandatory and free of charge. Nevertheless, the lack of democratic traditions, especially in the beginning of the period, and the strong influence of the monarch, distorted the political system. For this reason, some historians define the political system in this period as "quasi-pluralism" (Balkansky et al. 1999).

In that period, the fundamentals of the educational system were established. The state and the central government had full responsibility for the administration and financial support of education. In the end of the 19th century, six-year mandatory education was introduced, as well as mandatory pre-school education. The teachers became civil servants and standardized criteria for their preparation were implemented.

In the end of 19th century, for the first time, the school subject civics was introduced. The subject was mandatory for students at the end of primary education (grade 7). Thus, the State aimed to provide every student who graduated from primary school with the knowledge and skills necessary to act as a competent citizen of the country. The main content areas of civic education during that period were democracy and what it means to be governed by a parliament; the constitution; citizens' rights, freedoms, and responsibilities; and, relationships between the individual, society, and state institutions. In 1894, the first textbook in civics was published.

The establishment of the totalitarian communist regime after 1944 changed the political orientation of the Bulgarian state and the educational paradigm. Civic-related subjects were taught according to the principles of communist ideology. A new school subject was introduced, scientific communism, which represented the main ideas in Marxist doctrine and Leninism (Zahariev et al. 2001). 
In 1989, the Communist party resigned and the country started a process of political and socioeconomic reforms with a fundamental aim-restoration of the democracy. Major transformations were implemented, such as re-establishment of democratic institutions and structural reform in economy, culture, and education. De-ideologization was announced as one of the major goals in education. However, this has not been an easy transition since economic crisis, unemployment, increased crime rates, and corruption have accompanied the changes.

The National Education Act, adopted in 1991, regulated the process of de-idelogization in Bulgarian education during that period including civic and citizenship education. In 2000, the national educational standards for school content were implemented. According to these standards, civic and citizenship education was considered a part of the cultural and educational field "social science and citizenship education," and was taught through subjects like history, geography, and philosophy. In grade 11, a separate integrated subject, called the world and the individual, was introduced.

\section{Recent Changes in the Educational System that have Influenced Civic and Citizenship Edu- cation in Bulgaria}

Today civic and citizenship education has become a focus in education. It is a part of the reform effort in school education accomplished through the Pre-School and School Education Act in 2016. The Act outlines the major changes in the philosophy and goals of education in Bulgaria and defines school education as competence-oriented. Civic competences are one of the key competences that pupils should develop in the process of general education. The law defines 12 main objectives of pre-school and school education, at least seven of which are directly linked to civic and citizenship education:

- Acquiring the competences necessary for successful personal and professional realization and active civic participation in modern communities;

- Acquiring the competences for sustainable development;

- Acquiring the competences for understanding and implementation of democratic principles, human rights and freedoms, and active and responsible citizenship participation;

- Development of tolerance and respect for the ethnic, national, cultural, linguistic, and religious identity of every citizen;

- Development of tolerance and respect for rights of the child, students, and people with disabilities;

- Acquiring the competences for understanding global processes and their interrelations; and

- Acquiring the competences for understanding and implementation of the principles, rules, responsibilities, and rights resulting from participation in the European Union.

The Pre-School and School Education Act outlines the social and citizenship competences as one of the main groups of competences which students have to develop during general education. In general, the aim is to enhance the activity and involvement of young people in political and social processes.

The concept of civic and citizenship education is also presented in the National Child Strategy (2008-2018) and is discussed in the context of the challenges and risks for child development. The fourth operational objective of the Strategy is to promote children's participation in the development and implementation of policies related to their rights and responsibilities. Acquiring clear understanding of the development of tolerance, adaptivity, and emotional intelligence is important. 


\section{Studies of Civic and Citizenship Education in Bulgaria and their Main Findings}

\section{International Studies on Civic and Citizenship Education in which Bulgaria Participates}

Bulgaria continues to participate in the international assessment surveys of the International Association for the Evaluation of Educational Achievement (IEA), including CIVED, ICCS, PIRLS, and TIMSS, ${ }^{2}$ and the Organisation for Economic Co-operation and Development (OECD), including PISA and TALIS. ${ }^{3}$ The national findings of these projects provide detailed information about the quality of education in several key areas: reading, mathematics, science, and civic and citizenship education.

Bulgarian students participated in the three civic education studies that IEA organized after the radical political and social changes that took place in the 1980s and 1990s. Bulgarian students took part in IEA's CIVED in 1999 together with about 90,000 14-year-old students in 28 countries. After almost 10 years, Bulgarian grade 8 students and their teachers participated in the new civic education study ICCS 2009, and later in ICCS 2016. This allowed, on the one hand, measuring of the knowledge, skills, and attitudes of students in civic and citizenship education at the time and, on the other, identifying changes that have occurred in the preparation of pupils over a relatively long period.

In 1999, with a mean knowledge score of 98 points, Bulgarian grade 8 students were in the group of countries with a mean result that did not differ significantly from the average score for CIVED of 100 points (Torney-Purta et al. 1999). In 2009, the mean result of Bulgarian students was 466 points, which was significantly lower than the ICCS 2009 international mean of 500 points (Schulz et al. 2010; Petrova 2010, pp. 229-241). Bulgaria was among the 11 countries that achieved a lower average score in 2009 in comparison with 1999, and the decrease was the largest in Bulgaria. Subsequently in ICCS 2016 the result of Bulgarian pupils increased compared to the survey in 2009. Nevertheless, the mean result for Bulgarian students of 485 points was again lower than the survey average of 517 points (Schulz et al. 2018; Petrova 2018). The findings in 2009 and 2016 showed that girls in Bulgaria had a higher score than boys. For example, in 2009, their score was higher by 26 points, and in 2016 the difference was 37 points. Indeed, in almost all countries, the girls outperformed boys. The largest gender differences were identified in Malta and Bulgaria.

The findings showed that the social and cultural background of students has a strong impact on their achievements in civic and citizenship education. The students with higher social and cultural status had higher mean scores than the students with lower social status. The difference between the results of students in the two extreme categories according to the educational status of their parents was the largest in Bulgaria compared to the other countries in the study. The findings and interpretations based on various studies, including PISA (OECD 2016), have suggested that the inequality in results on the civic education test in Bulgaria are likely a result of the extent of economic and social inequality in the country. To put it another way, the social and family status of the students is a strong predictor of the students' achievements in civic and citizenship education. The family's influence is also visible in other results. The students whose parents are more interested in political and social issues are more likely to expect to engage with civic activities in the future.

2 CIVED = Civic Education Study; ICCS = International Civic and Citizenship Education Study; PIRLS = Progress in International Reading Literacy Study; TIMSS = Trends in International Mathematics and Science Study.

3 PISA = Programme for International Student Assessment; TALIS = Teaching and Learning International Survey. 
The results from ICCS 2016 showed that the civic knowledge and skills of students varies considerably within as well as between countries. The biggest difference between the highest and lowest results of the students in ICCS 2016 (the amount of variance) was measured in Bulgaria. For example, the difference between the five percent of students with the lowest scores and five percent of students with the highest scores was 349 points. It was 275 points for ICCS 2016 internationally. Although most of the students in Bulgaria possess basic knowledge in civics, the percentage of those who achieved high results in the survey was very small while there were many low achievers. This suggests that efforts should be focused on motivation and support for lower achievers and ensuring their effective inclusion in the learning process.

The results of ICCS 2016 confirmed ICCS 2009 conclusions showing somewhat inconsistent links between high test scores and the motivation of the students to participate in civic activities. For example, top performing students in Bulgaria are more likely to vote in elections in the future, but they do not plan to engage in active political life as adults. This is also true in many other participating countries.

Compared to other participants in the survey, Bulgarian students are more likely to participate in social campaigns and express their position and opinion on significant public or political issues. In addition, significantly more students tend to be involved in legal and illegal forms of protest than in other countries. Bulgaria has a relatively high average scale score for anticipated participation in illegal protest activities -54 points (50 points on average for ICCS). Students who expected to participate in illegal protest activities tended to have lower levels of civic knowledge.

However, almost half of students in Bulgaria do express strong support for democratic beliefs. For example, they agree that people should have equal rights regardless of their gender or ethnic origin. This attitude is much more pronounced among students with higher test scores and among girls. On the other hand, compared to other countries in ICCS 2016 there are significant differences between perceptions of pupils in Bulgaria and their peers about the equality and equal rights of ethnic groups. The index score of Bulgarian students is one of the lowest in the survey -49 points (53 points on average for ICCS). Bulgarian students across the studies have moderate levels of support for women's rights compared to other countries in ICCS and report relatively closed (rather than open) classroom climates for discussion.

Students report gaining their information about political and public issues primarily from television and their parents. They usually do not read newspapers. The use of social media as an environment for civic activities and the exchange of information on civic issues is still very limited. The comparison of students' engagement with social media and their socio-cultural status indicates very weak association. The difference between social media engagement of students by parental education is not statistically significant.

Students in the schools where conditions encourage civic activities among students, where students are involved in the development of school policy, and where the students participate in school life, are more motivated to participate in civic initiatives out of school. The main areas of students' activities in the schools are sports and cultural events. On the other hand, the number of Bulgarian students who participate in activities related to student self-government is relatively small.

The data showed that Bulgarian pupils are more actively involved in civic initiatives outside school than at school. Compared to 2009, more students in 2016 report being involved in discussions on political and social issues; their confidence in participating in various civic initiatives has also increased. Positive change was also observed in pupils' attitudes towards participation in civic initiatives in the future. The share of students participating in volunteer activities rose substantially in ICCS 2016 compared to ICCS 2009. The ICCS 2016 data showed that the students who participate in various civic initiatives at schools have more positive attitudes and are more likely 
to participate in civic activities in the future. That means that the school has a potential not only to teach civic knowledge and develop skills but also to create positive attitude toward active civic behavior among young people.

\section{National Studies on Civic and Citizenship Education}

Along with the international studies of civic and citizenship education, several national surveys have been conducted in Bulgaria among young people, mainly supported by non-governmental organizations (NGOs). The results of these studies to a great extent confirmed the findings from ICCS.

In 2005, the Bulgarian Gender Research Foundation implemented a national survey on young people's civic participation-Young People and Civil Society in Bulgaria. The main objective was to investigate young people's attitudes towards civic participation, different mechanisms of participation, and attitude to NGOs. The surveyed group included young people aged 16-30. The methods were questionnaires, focus groups, interviews with members of youth political organizations, content analyses of articles, and interviews with youth leaders. The survey results identified several groups among young people according to their attitudes to civic and citizenship education related issues and active civic participation. The respondents (especially the youngest group) believed that participation in political parties and civic organizations were not important. More than half of 16 and 17 -year-olds declared that they are not interested in social and political life. The youngest group was least likely to be included in the discussion about socio-political events in the family, with friends, or at school/work. The 16 to 17 -year-olds demonstrated the least willingness to participate in activities such as volunteering or circulating petitions. The survey found a contradictory understanding of the state's role in social life as a guarantee of social equality, on the one hand, and citizen autonomy and the role of the civic society in policy development, on the other. The opinion that the state should ensure a basic income to everyone and guarantee social equality was dominant. In terms of the effective ways for influencing the government's decisions, nearly $43 \%$ of the respondents answer that there is no way to influence governmental decisions; $37 \%$ consider strikes and protests as the most effective ways to influence the government; and 14\% of respondents preferred a dialogue with the government such as meetings and negotiations (Bulgarian Gender Research Foundation 2005).

In 2014, the Bulgarian Youth Study was carried out as a part of the Friedrich Ebert Foundation's research project on youth in the Balkan countries (Kovacheva and Kabaivanov 2016; Kovacheva and Mitev 2014). The methodology of the study combined standard interviews with respondents aged 14-27 and in-depth interviews with young males and females in different social circumstances. The research instrument covered the attitudes and experiences of young Bulgarians in a wide range of life domains: family, school, work, leisure, and politics. The survey collected these data on the values and behaviors of young people in Bulgaria in order to understand their life choices. The data allowed for the drawing of profiles of the young people in terms of civic attitudes, values, and civic participation. The group of young people who were involved in informal voluntary activities tend to be in their teens or early twenties, in stable jobs, with a strong trust in European institutions and the media, a high interest in international politics, and a firm belief that being active in civic activities is a modern way of expressing their opinion.

The membership in non-profit organizations as a form of civil engagement is very low among young people in Bulgaria, according to the survey data (some 15\% of the respondents were members of an organization). Those active in formal youth or other NGOs share high trust in political parties in Bulgaria and the country's parliament, as well as in European institutions. Trust in political parties, the government, and the European institutions have a positive relation to the involvement in elections and voluntary activities. 
Youth who participate in elections are more likely to live in rural areas and trust local authorities more than the central government. They trust local politicians and parties more.

The survey results suggest a lack of representation of youth in politics, which is seen as a remote domain, reserved mainly for politicians.

\section{Current Debates in Civic and Citizenship Education}

Civic and citizenship education became a matter of public interest and debate during the development and adoption of the Pre-school and School Education Act (2016). A key point in the discussions was what type of civic and citizenship education should be implemented in the Bulgarian schools. During recent years, discussions about the aims, content, and methodology of civic education are taking place at all levels: teachers, education experts, university professors, trade unions, and the NGO sector.

There is agreement on two major issues: the civic competences of the students should be developed during school education, and civic and citizenship education is not a typical school subject. There are several main characteristics of civic and citizenship education, which are explicitly defined in the normative documents about school education in Bulgaria: interdisciplinary, systematic, purposeful and pragmatic, and relevant to the everyday life of the students; with a global outlook; emphasizing the importance of pluralism and diversity of views; and using discussion, debate, and dialogue as learning tools (Ordinance № 13/21 September 2016).

The current concept of civic and citizenship education in Bulgaria reflects experts' agreement that the social mission of civic education is to harmonize the relationship between the individual and the state and to promote the successful integration of young people in society. That can be achieved through a combination of civic knowledge, skills, and competencies necessary for active participation in social and civic life. It is essential for students to acquire knowledge about the state, democracy, society, law, politics, economics, culture, ethics, ethnicity, and ecology. Among the important social skills that a good citizen should possess are those necessary to perform diverse social roles in the family, groups, communities, and society; to think critically, to argue, and also to negotiate. Skills for developing projects and communicating with people from different countries and different social groups along with competencies in decision-making, teamwork, and conflict resolution are valuable.

While there is agreement about the social mission of civic and citizenship education, there is controversy about the educational policies and practices through which this mission should be accomplished. The different points of view concern the approach to civic education in the Bulgarian schools, i.e., to study civic and citizenship education as a separate subject or based on an interdisciplinary approach. The proponents of citizenship education as a separate school subject argued that such an approach would result in a more holistic and systematic curriculum. According to this view, the teaching of citizenship education as a freestanding discipline would avoid the confusion of introducing some concepts differently depending on the particular contexts of the different subjects. The proponents of this concept argue that civic and citizenship education should be accepted as an integral but independent part of the common educational process.

Another approach is teaching civic and citizenship education in an interdisciplinary way that crosses the curriculum. The proponents of this approach argued that the nature of citizenship education is interdisciplinary and therefore the cross curricular approach is most appropriate to study the subject. They argue that this approach ensures the effective linkages among the various subjects.

Currently the Bulgarian educational system adopts a vision for civic and citizenship education that is a combination between two mentioned approaches. According to Ordinance № 13/21 (2016) civic, health, ecological, and intercultural education are interrelated and form an interdisciplinary 
complex aimed at development of social, civil, and intercultural competences. Civic and citizenship education is intended to be an integral component in all subjects, at all educational levels. It exists also as a separate school subject, civil education (previously, the world and the individual), in grades 11 (will be introduced from 2020-2021 school year) and 12 (will be introduced from 2021-2022 school year). It is defined not as a theoretical course but as an opportunity for the students to apply citizenship competences in practice by focusing on developing practical skills and abilities.

According to the curriculum in this area, half of school time should be allocated for practical activities and practice. In addition, civic and citizenship education is an integral part of extracurricular activities in and outside of the school. Schools are obliged to support, to build and maintain a democratic school organizational culture encouraging respect for shared understandings, traditions, and common values. Its features include such democratic practices as students' self-management, volunteering, youth leadership, informal groups, school media, and peer education. Every school is obliged to develop and implement institutional policies for supporting civic, health, environmental, and intercultural education. Each school is also expected to develop its own ethical code.

Nevertheless, many agree that civic and citizenship education in Bulgarian schools is still not as good as it should be. Discussions are taking place on the content and methods of teaching in this area. There is general agreement that Bulgarian school education is still subject oriented. Civic and citizenship education is taught theoretically, and its practical orientation is neglected. In order to turn it into an involving activity that encourages pupils' initiative, creativity, and responsibility, civic and citizenship education should be based on interaction such as debates or discussion, learning through practice or experience, inquiry, problem solving, case studies, and project development. It must also include such specific activities as school parliament and organized projects to encourage civic participation in school life and to promote democratic discussion and ethics in schools.

Consultation with teachers, educational experts, and university lecturers conducted in preparing this chapter identifies the main obstacles for the effective implementation of civic and citizenship education in schools. Some of the obstacles are rooted in the curricula. The curriculum includes a large number of topics but the teaching time is insufficient, especially considering what could be the practical orientation of civic education. This has an impact on teachers' and students' motivation to engage in discussing or suggesting ways to solve civic related issues. The teaching time for development of social skills and civic competencies through individual and teamwork is extremely limited. Education resources appropriate for teaching civic and citizenship education are also insufficient. Another obstacle according to the respondents is that many teachers do not have appropriate theoretical and methodological preparation to teach the subject.

The educational systems define as their main aim the development of the abilities of all students regardless of their family and social status. Indeed, in many countries including Bulgaria the socioeconomic background of the students has a decisive impact on their education achievements and on their education opportunities. That is why equity in education is an important condition for social justice and inclusion.

CIVED results as well as the results from two ICCS surveys enabled an in-depth exploration of civic and citizenship education in the Bulgarian schools. The national data were analyzed in the international context of the information about civic and citizenship education in other countries in the surveys. We were able to study the local as well as national contexts and the interrelation between schools and the local communities; the resources for civic and citizenship education at local level; problems related to the teachers' qualification and in-service training; the specific civic content, assessment approaches, and instruction methods. These provided motivation 
for considering educational policies and even some innovations aimed to impose a culture of creativity, flexible learning models, and use of a variety of educational resources (Petrova 2010; 2012; 2018).

\section{Teachers of Civic and Citizenship Education}

Civic education in Bulgaria is taught mainly by history, geography, and philosophy teachers with relevant bachelor or master's degrees as it is introduced in the learning content of these subjects. In-service teachers' training on civic education is on an optional basis. Initial and in-service training of teachers is provided mainly in the universities in the form of qualification programs, seminars, refresher courses, etc.

In 2014, a National Strategy for Teachers Development (2014-2020) was adopted with the aim of creating conditions for attracting young people to the teaching profession. In recent national strategies and policy documents, the Ministry of Education and Science recognizes the increasing shortage of teachers due to the aging population in the profession. The National Strategy for Teachers' Development (2014-2020) outlines as a priority the recruitment, retention, and professional development of teachers less than 35 years old. Moreover, it identifies strategic measures such as mentoring programs, on-going professional development for novice teachers, and alternative models for obtaining teacher qualification. There are also measures to update the assessment of the teacher and his/her work as well as specific measures and policies for motivating, attracting, and retaining young pedagogical staff.

Under the new law, the Ministry of Education and Science develops and maintains an information register of approved teacher training programs many of which are focused on topics, teaching strategies, and approaches related to civic and citizenship education.

\section{Summary and Conclusions}

Participation of Bulgarian students in three IEA surveys of civic and citizenship education led to a growing interest in the civic education taking place in schools. It brought attention to the problems in civic and citizenship education, and they became a subject of discussions, seminars, conferences, national surveys, and publications.

The importance of civic and citizenship education stems from the fact that it is an integral part of the preparation of the young people for active participation in public life and democratic societies. Undoubtedly, civic education is not a typical learning subject. It is distinguished by its practical focus, which requires the application of interactive teaching and learning methods rather than the methods traditionally used in school. The students should be actively involved in the learning process through teamwork and project development. This approach sets very high requirements for the teachers in CCE both from content and methodological points of view.

The results of the Bulgarian grade 8 students in ICCS 2009 and 2016 put on the agenda the issue of the quality of civic and citizenship education in Bulgarian schools. As already mentioned, the average score of Bulgarian students was significantly lower than the average for ICCS. Also of concern is the great variation in the individual students' results and the strong influence of the socioeconomic status of the students on their achievements. This clarified that there is a problem and made clear the importance of examining the factors that influence the quality of civic education in school.

The overall conclusion of ICCS and other international assessments and surveys showed in the first place that the curriculum content, teaching methods, instruction, and teachers' qualification have an impact on the academic achievements of the students, and on their motivation and interest in civic and citizenship education. Thus, the need for a re-organization of school instruction, school content, teaching strategies, resources, and methods was highlighted as a key point. 
As a result of the public awareness of ICCS 2009 and ICCS 2016 findings, topics that have been a subject of increased public interest over the last decade were added to the civic and citizenship education curriculum. These include the concepts of responsible citizenship and sustainable development; envisioning the school as a public area in which pupils can participate; the potential use of social media for gaining information and developing opinions about civil events (with care about the validity of sources); and the inclusion of topics related to global citizenship (to give just a few specific examples).

Although significant changes in school education in Bulgaria have been made in recent years, there are several topics of key importance, which are still debated. There are problematic areas that are directly related to the quality and efficiency of civic education in Bulgaria. The first issue is the conceptualization of civic and citizenship education in the Bulgarian school. It is of great importance that the concept of civic and citizenship education be discussed by emphasizing social expectations about the civic competences of the students that allow them to become active participants in socio-political practices in democratic society. The second issue is subject content, teaching, and learning methods. It is necessary to analyze the topics included in the curricula in terms of their relevance and significance. It is important to implement teaching and learning methods that arise from the nature of civic and citizenship education and ensure active participation of students in the learning process. The third topic is related to the teachers' qualifications, which is a key factor in achieving high quality education. Teachers and educational experts understand how important it is to participate regularly in training programs focused on specific issues of civic and citizenship education. The fourth issue is about the development of the school as a democratic institution that encourages open discussion and students' civic initiative. The school is the institution that plays a leading role in preparing young people as autonomous and responsible citizens who are aware of their value and role in society. ICCS data shows that Bulgarian pupils are more involved in the civic initiatives outside the school than at the school. The school should be strengthened as an institution that encourages students' civic participation. For this purpose, it also should become a place for the practice of active citizenship.

\section{References}

Balkansky, B., Zahariev, Z., Stoyanov, S., \& Stoyanova, N. (1999). Challenges in developing a new system of civic education in conditions of social change: Bulgaria. In J. Torney-Purta, J. Schwille, \& J-A. Amadeo (Eds.), Civic education across countries: Twenty-four national case studies from the IEA Civic Education Project. Amsterdam, the Netherlands: International Association for the Evaluation of Educational Achievement (IEA).

Bulgarian Gender Research Foundation. (2005). Young people and civil society in Bulgaria.

Constitution of the Republic of Bulgaria [Конституция на Република България] (1991). Sofia: State Gazette, 56/13 July 1991.

Наредба 5/30.11.2015 за общообразователната подготовка [Ordinance № 5/30 November 2015 on the educational preparation] (2015). Sofia, Bulgaria: State Gazette, 45/08 December 2015.

Наредба 13/21.09.2016 г. за гражданското, здравното, екологичното и интеркултурното образование [Ordinance № 13/21 September 2016 on Civic, Health, Ecological and Intercultural Education] (2016). Sofia, Bulgaria: State Gazette, 80/11 October 2016.

Наредба № 12 за статута и професионалното развитие на учителите, директорите и другите педагогически специалисти [Ordinance № 12 on the status and professional development of teachers, directors and other pedagogical specialists] (2016). Sofia, Bulgaria: State Gazette, 75/27 September 2016.

Наредба за държавните изисквания за придобиване на професионална квалификация „учител” [Ordinance for state requirements for acquiring a teacher's professional qualification] (2016). Sofia, Bulgaria: State Gazette, 89/11 November 2016.

Kostov, K. (2018). Civil education in Bulgarian school after 1989 [Гражданското образование в българското училище след промените от 1989]. Strategies for Policy in Science and Education, 26(2), 173-181. 
Kovacheva, S., \& Kabaivanov, S. (2016). Differences and inequalities in civic participation among Bulgarian youth. Sociology and Anthropology, 4(4), 228-240.

Kovacheva, S., \& Mitev, P.-E. (2014). Young people in European Bulgaria. A sociological portrait. FriedrichEbert-Stiftung. https://library.fes.de/pdf-files/bueros/sofia/12569.pdf

Ministry of Education and Science. (2014). Национална стратегия за развитие на педагогическите кадри (2014-2020) [National Programme for Teachers Development (2014-2020)]. Sofia, Bulgaria: Ministry of Education and Science.

Mitropolitski, M., Gjurova, V., Bojadzieva, N., Petrov, D., Savova, J., Koleva, N., \& Kostova, Z. (2001). Civic education. Sofia, Bulgaria: National Institute of Education.

Organisation for Economic Co-operation and Development (OECD). (2016). PISA 2015 results (Volume 1): Excellence and equity in education. Paris, France: OECD Publishing. https://doi. org/10.1787/9789264266490-en.

Petrova, S. (2010). Гражданско образование и гражданска активност на учениците. Резултати от участието на България в Международното изследване на гражданското образование - ICCS 2009 [Citizenship education and civil activity of the students. Results of Bulgarian students in the IEA International Civic and Citizenship Education Study - ICCS 2009]. Strategies for Policy in Science and Education, 18(4).

Petrova, S. (2012). Възприятия, нагласи и ценности на българските ученици в областта на гражданското образование - по данни на Международното изследване на гражданското образование [ICCS civic perceptions, values and attitudes of Bulgarian students. National findings from ICCS 2009]. Pedagogy: Educational Journal, 84(1), 56-67.

Petrova, S. (2018). Възприятия и нагласи на учениците по важни обществени въпроси (Данни от международното изследване на гражданското образование - ICCS 2016) [Attitudes and perceptions of students towards important civic issues (ICCS 2016 data from the international study on citizenship education)]. Strategies for Policy in Science and Education, 26(1), 75-100.

Schulz, W., Ainley, J., Fraillon, J., Kerr, D., \& Losito, B. (2010). ICCS 2009 international report: Civic knowledge, attitudes, and engagement among lower-secondary school students in 38 countries. Amsterdam, the Netherlands: International Association for the Evaluation of Educational Achievement (IEA).

Schulz, W., Ainley, J., Fraillon, J., Losito, B., Agrusti, G., \& Friedman, T. (2018). Becoming citizens in a changing world. IEA International Civic and Citizenship Education Study 2016 international report. Cham, Switzerland: Springer. https://doi.org/10.1007/978-3-319-73963-2

The Pre-School and School Education Act [Закон за предучилищното и училищното образование] (2016). Sofia: State Gazette, 79/13 October 2015.

Torney-Purta, J., Lehmann, R., Oswald, H., \& Schulz, W. (2001). Citizenship and education in twenty-eight countries: Civic knowledge and engagement at age 14. Amsterdam, the Netherlands: International Association for the Evaluation of Educational Achievement (IEA).

Torney-Purta, J., Schwille, J., \& Amadeo, J. (1999). Civic education across countries: Twenty-four national case studies from the IEA Civic Education Project. Amsterdam, the Netherlands: International Association for the Evaluation of Educational Achievement (IEA).

Open Access This chapter is licensed under the terms of the Creative Commons Attribution-NonCommercial 4.0 International License (http://creativecommons.org/licenses/by-nc/4.0/), which permits any noncommercial use, sharing, adaptation, distribution and reproduction in any medium or format, as long as you give appropriate credit to the original author(s) and the source, provide a link to the Creative Commons license and indicate if changes were made.

The images or other third party material in this chapter are included in the chapter's Creative Commons license, unless indicated otherwise in a credit line to the material. If material is not included in the chapter's Creative Commons license and your intended use is not permitted by statutory regulation or exceeds the permitted use, you will need to obtain permission directly from the copyright holder. 